NASA Technical Memorandum 100107

\title{
Liner Cooling Research at NASA Lewis Research Center
}

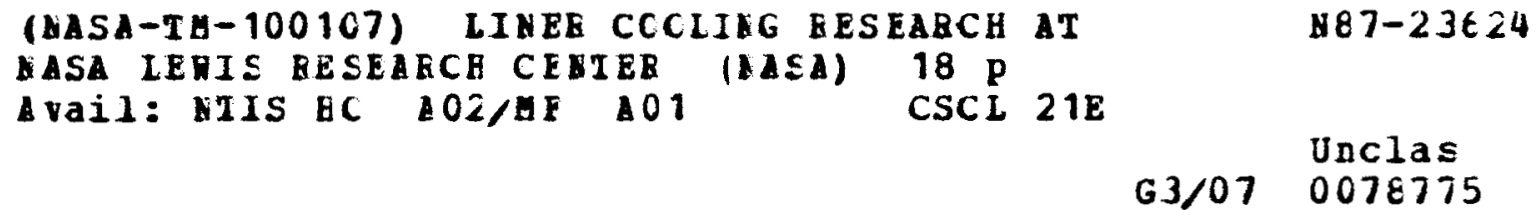

Waldo A. Acosta

Propulsion Directorate

U.S. Army Aviation Research and Technology Activity-AVSCOM

Lewis Research Center

Cleveland, Ohio

Prepared for the

23rd Joint Propulsion Conference

cosponsored by the AIAA, SAE, ASME, and ASEE

San Diego, California, June 29-July 2, 1987

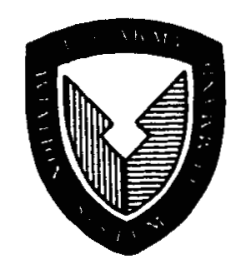




\title{
LINER COOLING RESEARCH AT NASA LEWIS RESEARCH CENTER
}

\author{
Waldo A. Acosta \\ Propulsion Directorate \\ U.S. Army Aviation Research and Technology Activity - AVSCOM \\ Lewis Research Center \\ Cleveland, Ohio 44135
}

\section{SUMMARY}

This paper describes recently completed and current advanced liner research applicable to advanced small gas turbine engines. Research relating to the evolution of fuel efficient small gas turbine engines capable of meeting future commercial and military aviation needs is currentiy underway at NASA Lewis Research Center: As part of this research, a reverse-flow combustor geometry was maintained while different advanced liner wall cooling techniques were investigated and compared to a baseline combustor. The performance of the combustors featuring counter-flow fllm-cooled liner (CFFC) panels, transpiration cooled liner walls (TRANS), and compliant metal/ceramic (CMC) walls was obtained over a range of simulated flight conditions of a 16:1 pressure ratio gas turbine engine and fuel air ratios up to 0.034 . All the combustors featured an identical fuel injection system, identical geometric configuration outline, and similar designed internal aerothermodynamics.

\section{INTRODUCTION}

Problems unique to small combustors were reviewed during a forum at NASA Lewis conducted by A.D. Littie, Inc. (ref. 1). The objective was to identify the R\&D effort which must be considered in the 1980 to 1990 time frame to meet the critical needs for small alrcraft gas turbines. Advancements in gas turbine cycle efficlency and lowered specific fuel consumption were primary considerations. These improvements can be realized by increasing cycle pressure ratios and turbine inlet temperature, and/or implementing either regenerative or recuperative cycles. Combustors operating at these conditions require increased amounts of cooling air. At the same time, the heat sink capability of the air has been decreased because of higher combustor inlet temperature resulting from increased pressure ratio and/or regenerative cycle operation. This loss in heat sink capability is particularly critical in the small combustor system due to the inherent high surface-to-volume ratio as compared with large combustion systems. It was the concensus of the participants in the forum that liner cooling was one of the most important areas that should be considered. Advanced cooling techniques must be incorporated in the combustor in order to achieve the potential for implementing advanced cycles.

The liner cooling approach predominately used in present day small gas turbine combustors is splash film cooling. The cooling air enters the liner through a row of small diameter holes. The air jets impinge on a cooling skirt, which then directs the flow so as to form a film along the inside of the liner wall. The total amount of cooling air required depends on a number of factors; however, typical values range from 30 to 50 percent of the combustor airflow. Improvements in liner cooling effectiveness can be achieve by using a more efficient air distribution and the heat sink available in the cooling 
air (ref. 2). Another alternative is the use of advanced materials that require little or no cooling.

A component research program for advanced small gas turbine engines was initiated as a result of the forum's recommendations and is currently underway at NASA Lewis. The objective of the program is to identify and evaluate new and promising liner cooling techniques for advanced combustors.

In this paper, a reverse flow combustor equipped with different advanced liner designs operating at advanced cycle conditions is presented. The performance of the combustor was obtained over a range of simulated flight conditions of a 16:1 pressure ratio gas turbine engine and fuel air ratios up to 0.034 . This is an extension to the work previously reported in which the combustors were operated at fuel air ratios up to 0.024 (refs. 3 and 4 ).

In addition to the reverse flow combustor liner research being conducted additional liner research currently in progress is described. These activities consist of a compliant metal/ceramic experimental combustor program with Allison Gas Turbine Engine Operations and a more fundamental liner test rig designed to screen advanced liner cooling techniques.

\section{APPARATUS}

\section{Test Facility}

The combustor was mounted in duct $A$ of the test facility CEgB (fig. 1) located in the Engine Research Bullding (B1dg. 5) at NASA Lewis. Tests were conducted with inlet-air pressure ranging up to $16 \mathrm{~atm}$ with the air indirectly heated to about a temperature of $717 \mathrm{~K}\left(830^{\circ} \mathrm{F}\right)$. The temperature of the air was automatically controlled by mixing the heated air with varying amounts of cold by-pass alr. Airflow through the heat exchanger and by-pass flow system and the total pressure of the combustor were regulated by remotely controlled values.

\section{Combustors}

The basic reverse flow combustor used in this investigation was a full scale experimental design. The design was based on versatility so that the interchanging of fuel injectors and the modification or replacement of the swirlers, faceplate, and liner could be readily accomplished. The airflow distribution and hole sizing of the liner were based on 36 primary holes and 36 dilution holes. The design liner isothermal pressure loss is 1.5 percent and the dump loss is 0.24 percent. A cross section and isometric views of the combustor are shown in figure 2 .

Transpiration (TRANS) liner. - Lamilloy was used to simulate transpiration cooling (continuous mass flux of coolant over the surface). A Lamilloy is a commercial product composed of an electrochemically etched channel structure in multilayers which is diffusion-bonded forming a sheet. This channel and multilayer structures allow the use of the heat sink capability inherent in the coolant air prior to injection into the combustion gases. An isometric sketch of the material is shown schematically in figure 3 : 
The Lamilloy combustor was fabricated under government contract to be similar to the reverse flow film-cooled geometry and to interface with the existing NASA test facility. The basic design conditions were for a peak combustor operating pressure of $16 \mathrm{~atm}, 717 \mathrm{~K}\left(830^{\circ} \mathrm{F}\right)$ inlet temperature, and $1930 \mathrm{~K}\left(2500^{\circ} \mathrm{F}\right)$ exit with hot streaks up to $1922 \mathrm{~K}\left(3000^{\circ} \mathrm{F}\right)$. Design details are presented in reference 5 .

Counter-flow film-cooled (CFFC) liner. - The CFFC liner design incorporated the use of fins to increase the heat transfer. The prime objective was to determine among the existing and avallable offset-fin tooling, a configuration that would ensure acceptable wall temperature and minimum friction losses. The final fin and channel height was based on producing the most significant wall temperature reduction for a given pressure loss and existing tool dies. The offset fin plates were distributed along the inner and outer cylindrical liners. The cross section of the CFFC liner shown in figure 4 shows the different cooling techniques employed.

The CFFC combustor liner was fabricated under government contract by the Garret Turbine Engine Company. The basic design conditions were the same as for the TRANS liner. More detalls about its design can be found in reference 6 .

Compliant metal/ceramic (CMC) liner. - The objective of the CMC liner program was to investigate advance liner concepts capable of withstanding temperature levels of $1922 \mathrm{~K}\left(3000^{\circ} \mathrm{F}\right)$, while providing improved cyclic durability with little or no cooling air. The CMC concept consisted of plasma spraying an yttria partially stabilized zirconia (YPSZ) on a compliant nickel alloy substrate. This compliant metal substrate was designed to yield at relatively low levels of stress, thereby absorbing the differential expansion between the metal and the ceramic as the material is heated. Figure 5 shows a cross-sectional view of the CMC liner concept.

In this first order approach it was elected to limit the combustor outlet temperature to approximately $1789 \mathrm{~K}\left(2760^{\circ} \mathrm{F}\right)$ rather than strive for the original $1922 \mathrm{~K}\left(3000^{\circ} \mathrm{F}\right)$ goal. This allowed the major simplification of using only backside convective cooling.

\section{INSTRUMENTATION}

The combustor instrumentation stations are shown in figure 6 . Five total pressure probes, two static pressure taps, and four Chromel-Alumel thermocouples are located at station 2 to measure the inlet pressure and temperature. At station 3, a series of 18 total pressure probes are installed to determine the inlet-air profile and to determine the extent of any flow disturbance behind the struts which support the centerbody diffuser. At station 4, six pitot-static probes are positioned in the cold-air passages between the combustor liner and combustor housing to determine passage velocity and distribution. At station 5, outlet temperature and pressure measurements were obtained by means of a rotating probe. The probe contains three rakes spaced $120^{\circ}$ apart a five-position radial rake containing PT-PT 13 percent Rd thermocouples, a five-position total pressure rake, and a water cooled gas sampling rake. A $360^{\circ}$ travel with sampling at $10^{\circ}$ increments was used for the CFFC and CMC 1 iner programs. The TRANS liner program used a stationary probe at station 5 to 
measure outlet temperature and pressure. The probe had 12 temperature rakes evenly spaced with 4 probes/rake containing PT-PT 13 percent Rd thermocouples and four gas sample/pressure probes evenly spaced on the circumference.

\section{PROCEDURE}

\section{Test Conditions}

The experimental reverse flow combustor was operated at test conditions based on a gas-turbine engine cycle with a compressor pressure ratio of 16 . A tabulation of the test conditions used in this study is given in table 1 .

Simulated flight data were obtained at fuel-air ratios up to approximately 0.034 . The simulated combustor test conditions were based on a reference velocity of $5.49 \mathrm{~m} / \mathrm{sec}^{\circ}(18 \mathrm{ft} / \mathrm{sec})$. The reference velocity quoted was based on unidirectional total mass flow and the maximum cross-sectional area of the housing prior to the reverse turn (fig. 6).

The test program was conducted using Jet-A fuel with 18 simplex pressureatomizing fuel injectors with a flow number of 4.8 .

\section{Emission Measurements}

Exhaust gas samples were obtained according to the recommended procedures in references 7 and 8 . Exhaust gases were withdrawn through the four water cooled probes mounted approximately in the stator plane and in the center of the exhaust duct at station 5 ( $\mathrm{fig} .6)$. The gas sample temperature was held at approximately $423 \mathrm{~K}\left(302^{\circ} \mathrm{F}\right)$ in the electrically heated sampling line. Most of the gas sample entered the analyzer oven, while the excess sample was bypassed to the exhaust system. To prevent fuel accumulation in the sample line, a nitrogen purge was used before and during combustor ignition.

After passing through the analyzer oven the gas sample was divided into three parts, and each part was analyzed. Concentrations of oxides of nitrogen, carbon monoxide and carbon dioxide, and hydrocarbons were measured by the chemiluminescence, nondispersed-infrared, and flame ionization methods, respectively. Detalis of the gas analysis system are presented in reference 9 .

\section{RESULTS AND DISCUSSION}

Combustor research relating to the development of fuel efficient small gas turbine engines capable of meeting future commercial and military aviation needs is currently underway at NASA Lewis. The goal is to evolve the technology for reducing liner coolant flows by 50 percent or more for increased operating temperatures to $978 \mathrm{~K}\left(1300^{\circ} \mathrm{F}\right)$ inlet, $1922 \mathrm{~K}\left(3000^{\circ} \mathrm{F}\right)$ outlet and pressure ratios up to $30: 1$.

A component research program for advanced small gas turbine engines was initiated towards that goal. The following discussions summarize those activities. 
The objective of this program is to identify and evaluate new and promising liner cooling techniques for advanced combustors. The combustors evaluated incorporate advanced liner designs. The experimental study was performed under high pressure and temperature environments simulating those encountered in combustors operating under advanced cycle conditions. Previous experimental results have been reported in references 3 and 4 . In reference 3 results between a transpiration (TRANS) cooled liner (continuous mass flux of coolant over the surface) and a liner incorporating counter-flow film-cooled (CFFC) finned panels are presented. These two liners are considered advance metaliic designs and demonstrated reductions in liner coolant flow from 40 to 50 percent when compared to the reference splash film-cooled (SF) liner.

A new liner concept incorporating a compliant metal/ceramic (CMC) design is presented in reference 4. In that study a simplified compliant ceramic liner concept was selected to facilitate implementation into research hardware. This allowed using only backside convective cooling which was provided by the passage between the combustor wall and casing. The reduction in liner coolant for the CMC configuration is shown in figure 7 and compared with the TRANS and CFFC configurations using as a reference the SF configuration. The CMC 1iner coolant flow was reduced by 80 percent.

As shown, the TRANS, CFFC, and CMC liners had similar reductions in liner temperature, but the CMC 1 iner operated at exhaust temperatures $167 \mathrm{~K}\left(300^{\circ} \mathrm{F}\right)$ hotter than current practice. The most significant performance improvements resulting with the CMC liner are the reduction of liner coolant and the increase in turbine inlet temperature. The increase in turbine inlet temperature will allow the engine to increase its cycle efficiency and the reduction of coolant flow frees some air that could be used for turbine cooling or exit temperature pattern improvements.

A new series of experiments were conducted to study the performance of those liners at off-design conditions. Each liner was designed for a maximum liner temperature of $1200 \mathrm{~K}\left(1700^{\circ} \mathrm{F}\right)$ at a fuel air ratio of 0.025 and sea level take-off conditions. For this experiments fuel air ratios up to 0.034 were used.

A comparison of liner temperatures is shown in figure 8 . The pane 1 selected for comparison is the inner wall prior to the turn. In general, this is one of the most difficult areas to cool due to the depletion of the mass flow in the annular passage. The TRANS and the CFFC used about 1.4 percent of the total flow to cool this panel, while the CMC was uncooled. Even though the TRANS and the CFFC used the same amount of cooling the CFFC liner temperatures were an average of $139 \mathrm{~K}\left(250^{\circ} \mathrm{F}\right)$ cooler than the TRANS liner. This indicates a better cooling effectiveness for the finned panels than the transpiration panels assuming similar flame temperatures for this particular location.

The liner temperatures measured on the CMC liner were higher than the TRANS and CFFC liners for this particular panel up to a fuel air ratio of about 0.024 . This could be explained by the fact that this was an uncooled liner and the convective heat transfer was reduced by the low annular velocities in that region. At fuel air ratios greater than 0.024 the CMC liner temperature is lower than the TRANS liner. At this point the thermal barrier capability of 
the ceramic became evident. None of liners exceeded the $1200 \mathrm{~K}\left(1700^{\circ} \mathrm{F}\right) 1$ iner temperature 1 imit.

Compliant metal/ceramic combustor. - The results presented here showed the benefits of using the heat sink capability available in the cooling air and ceramic materials as thermal barriers to improve the performance of small gas turbine engine combustor liners. A more significant improvement could be obtained by combining both approaches.

A joint NASA/Army program was initiated and a contract awarded to Allison Gas Turbine Engine Division. The purpose is to design and experimentally evaluate a compliant metal/ceramic reverse flow combustor to operate at $1922 \mathrm{~K}$ $\left(3000^{\circ} \mathrm{F}\right)$ outlet temperature. The first phase of the study was the selection of the material for the composite matrix iliner. The approach was to conduct a literature survey, flow calibration, cooling effectiveness investigation, thermal stress calculations, and micro structural life predictions to facilitate the preliminary design of the combustor. The candidate materials have been reviewed and the material composition selected. Two design models were formulated and hardware built to experimentaliy confirm the model. These models will resolve the optimum material composition, thickness, cooling, and construction technique by characterizing flows, and heat transfer.

The second phase requires the implementation of the resulting material to the extent of full combustor preliminary design. The combustion performance of the combustor was analyzed using the three-dimensional aerodynamic combustor flow-field designated MARC-1. The gas temperature and fuel air ratio patterns as given by the three-dimensional code were used to estimate the temperatures of the inner and outer shells of the annular combustor for various combustion zones.

The compliant metal/ceramic concept selected is shown in figure 9 . This is basically the same concept used in the in-house activity with the exception of the coolant flow. The cooling air flows through holes on the metal support structure. These holes must be of a sufficient size, number, and distribution to allow the air to uniformly pass through the compliant layer, picking up heat until it reaches an opening between two adjacent ceramic tiles. It is important that the cooling air be properly balanced as it passes through the compliant layer so that the cooling be as uniform as possible no leaving uncooled hot spots. Preliminary analysis indicate that only 20 percent of total airflow will be needed for cooling. This represents a 40 percent liner cooling reduction over state-of-the-art combustors.

Ceramic matrix liner. - In recent years there has been a rapid growth in research and development aimed at introducing high temperature ceramic materials and/or ceramic composites into gas turbine engines which require little or no coolant and minimize or eliminate the need for strategic materials.

Many promising candidate materials have been developed during the past few years. Experimental evaluation of this materfals in a full size gas turbine combustor liner will become very expensive. This creates the need for a liner test rig in which this ceramic materials could be experimentally evaluated under realistic combustor environments. 
A contract was awarded to Teledyne CAE for the design and fabrication of a ceramic matrix combustor liner test rig compatible with the NASA Lewis facility shown in figure 1. Included in this objective is the cataloging of material properties and the ranking of candidate materials for use in gas turbine combustors. In addition to pure ceramic materials such as silicon nitrates and carbides other semimetallic materials will be considered.

The test rig being fabricated is shown in figure 10. The ceramic specimens form a square annulus, approximately $10.2 \mathrm{~cm}(4 \mathrm{in.})$ on a side by $20.3 \mathrm{~cm}$ ( 8 in.) long. Internal rig hardware permits flexible testing of simple, flat ceramic specimens. From 8 to 16 specimens, either 8.9 by $10.2 \mathrm{~cm}(3.5$ by 4 in.) or 8.9 by $5.1 \mathrm{~cm}$ ( 3.5 by 2 in.), in 4 independently controlled quadrants can be tested simultaneously in the rig. Three panel thicknesses are defined: $0.25,0.38,0.64 \mathrm{~cm}$. Panels in any one quadrant must be of the same thickness and all quadrants are filled to form the flow path.

The ceramic materials will be experimentally evaluated in an environment simulating advanced engine cycles. The test rig will provide temperatures up to $2200 \mathrm{~K}\left(3500^{\circ} \mathrm{F}\right)$ and pressures up to $2068 \mathrm{kPa}$ (300 psia) in efther reducing or oxidating environments.

\section{CONCLUSIONS}

1. The advanced metallic liner designs studied, transpiration and counterflow f $\{1 \mathrm{~m}$-cooled, demonstrated reductions in liner coolant from 40 to 50 percent when compared to the reference splash film-cooled liner, and performed very well under advanced cycle conditions.

2. Preliminary analysis indicate that the incorporation of transpiration cooling in the compliant metal/ceramic concept will pave the way for the application of fuel efficient, aggressive high temperature cycles to small gas turbine engines.

3. The test facllity described will provide a realistic combustor environment for the experimental evaluation of potential ceramic materials for combustor liners.

\section{REFERENCES}

1. Demetr1, E.P., Topping, R.F., and Wilson, R.P. Jr., "Study of Research and Development Requirements of Small Gas-Turbine Combustors, "ADL-83381-2, Arthur D. Little Inc., Cambridge, MA, Jan. 1980. (NASA CR-159796).

2. Colladay, R.S., "Analysis and Comparison of Wall Cooling Schemes for Advanced Gas Turbine Applications," NASA TN D-6633, 1972.

3. Norgren, C.T. and Riddlebaugh, S.M., "Advanced Liner-Cooling Techniques for Gas Turbine Combustors," AIAA Paper 85-1290, July 1985. (NASA TM-86952).

4. Acosta, W.A. and Norgren, C.T., "Small Gas Turbine Combustor Experimental Study - Compliant Metal/Ceramic Liner and Performance Evaluation," AIAA Paper 86-1452, June 1986. (NASA TM-87304). 
5. Petraits, J.J., "Design and Fabrication of Lamilloy Reverse Flow Combustor Liners," EDR-9803, Detroit Diesel Allison, Indianapolis, IN, Apr. 1979.

6. "Design Documentation Report, Counterflow Film-Cooled Combustor Program," Report 21-4007-A, Garrett Turbine Engine Co., Phoentx, AZ, June 1982, (NASA (R-167922).

7. "Control of Air Pollution from Aircraft and Aircraft Engines, Emission Standards and Test Procedures for Aircraft," Federal Register, Vol. 38, No. 136, Pt. 2, Tuesday, July 17, 1973, pp. 19088-19103.

8. "Procedure for the Continuous Sampling and Measurement of Gaseous Emissions from Aircraft Turbine Engines," SAE ARP-1256, Oct. 1971.

9. Norgren, C.T. and Riddlebaugh, S.M., "Effect of Fuel Injector Type on Performance and Emissions of Reverse-Flow Combustor," NASA TP-1945, 1981.

TABLE 1. - REVERSE-FLOW-COMBUSTOR TEST CONDITIONS

\begin{tabular}{|c|c|c|c|c|c|c|c|c|c|c|}
\hline \multirow{2}{*}{$\begin{array}{l}\text { Test } \\
\text { condi- } \\
\text { tion }\end{array}$} & \multicolumn{2}{|c|}{$\begin{array}{l}\text { Total } \\
\text { airflow }\end{array}$} & \multicolumn{2}{|c|}{$\begin{array}{l}\text { Inlet } \\
\text { pressure }\end{array}$} & \multicolumn{2}{|c|}{$\begin{array}{c}\text { Inlet } \\
\text { temperature }\end{array}$} & \multicolumn{2}{|c|}{$\begin{array}{l}\text { Reference } \\
\text { velocity }\end{array}$} & \multirow{2}{*}{$\begin{array}{l}\text { Simulated } \\
\text { compressor } \\
\text { pressure } \\
\text { ratio }\end{array}$} & \multirow[t]{2}{*}{ Comments } \\
\hline & $\mathrm{kg} / \mathrm{sec}$ & $\mathrm{lb} / \mathrm{sec}$ & $\mathrm{kPa}$ & psia & K & ${ }^{\circ} \mathrm{F}$ & $\mathrm{m} / \mathrm{sec}$ & $\mathrm{ft} / \mathrm{sec}$ & & \\
\hline $\begin{array}{l}A \\
B \\
C \\
D \\
E \\
F \\
G \\
H\end{array}$ & $\begin{array}{l}2.27 \\
3.05 \\
3.63 \\
1.23 \\
2.12 \\
1.83 \\
1.51 \\
1.23\end{array}$ & $\begin{array}{l}5 \\
6.71 \\
8 \\
2.70 \\
4.66 \\
4.02 \\
3.33 \\
2.70\end{array}$ & $\begin{array}{r}1014 \\
1358 \\
1620 \\
405 \\
862 \\
689 \\
517 \\
414\end{array}$ & $\begin{array}{c}147 \\
197 \\
235 \\
58.5 \\
125 \\
100 \\
75 \\
60\end{array}$ & $\begin{array}{l}686 \\
703 \\
717 \\
474 \\
627 \\
581 \\
526 \\
474\end{array}$ & $\begin{array}{l}775 \\
805 \\
830 \\
394 \\
668 \\
585 \\
486 \\
394\end{array}$ & $\begin{array}{l}5.5 \\
5.5 \\
5.5 \\
5.2 \\
5.5 \\
--- \\
--- \\
---\end{array}$ & $\begin{array}{l}18 \\
18 \\
18 \\
16.9 \\
18 \\
- \\
- \\
-- \\
---\end{array}$ & $\begin{array}{l}10 \\
13.4 \\
16 \\
4 \\
8.5 \\
6.8 \\
5.1 \\
4.1\end{array}$ & $\begin{array}{l}\text { High-altitude cruise } \\
\text { Low-altitude cruise } \\
\text { Sea level take-off (SLTO) } \\
\text { Idle: f/a }=0.008 \\
\text { Simulated reduced power }\end{array}$ \\
\hline
\end{tabular}

aparametric variation based on increase in mass flow to provide increases of 33 and 66 percent in reference velocity. 


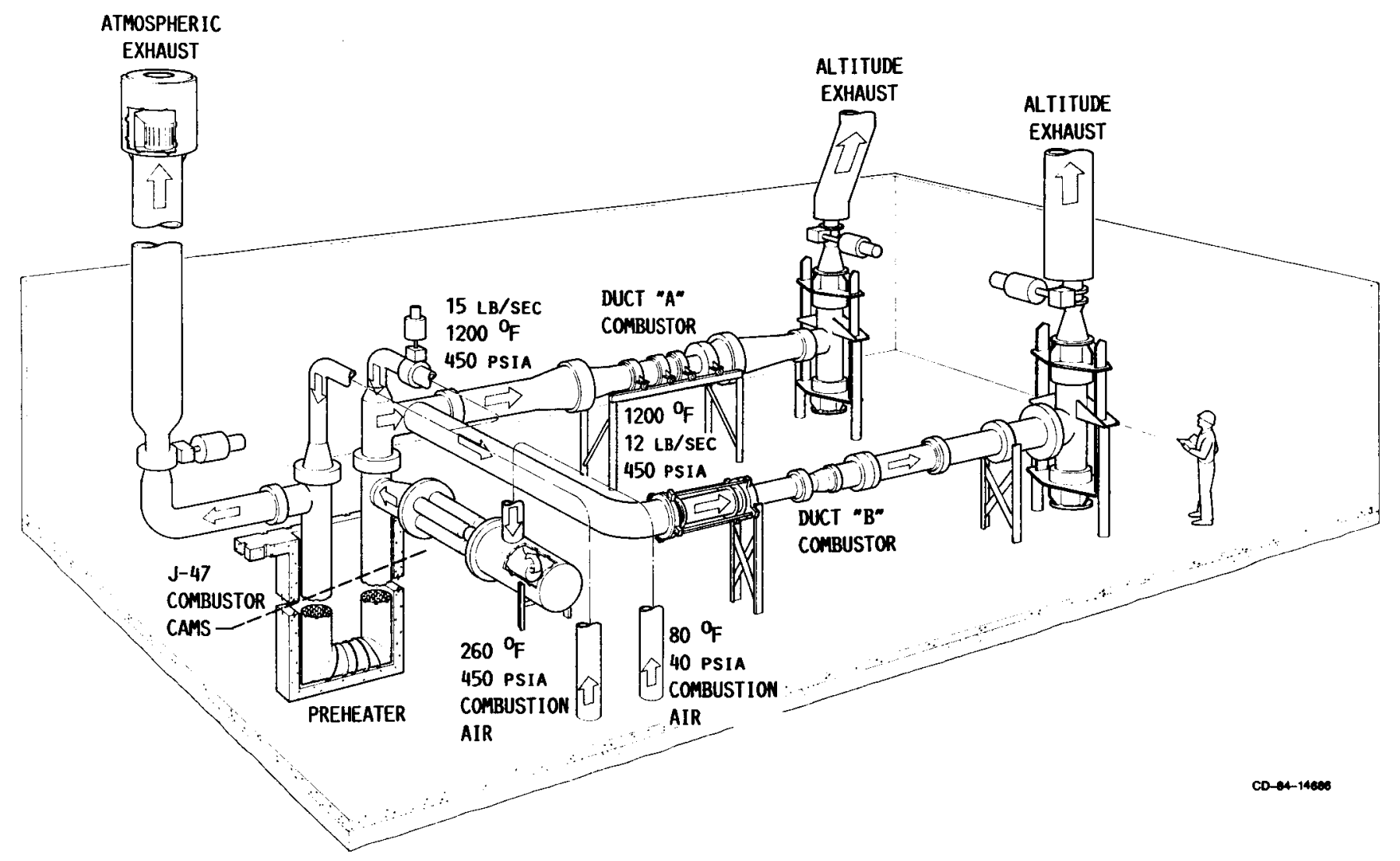

FIGURE 1. - SKETCH OF CLOSED-DUCT TEST FACILITY. 


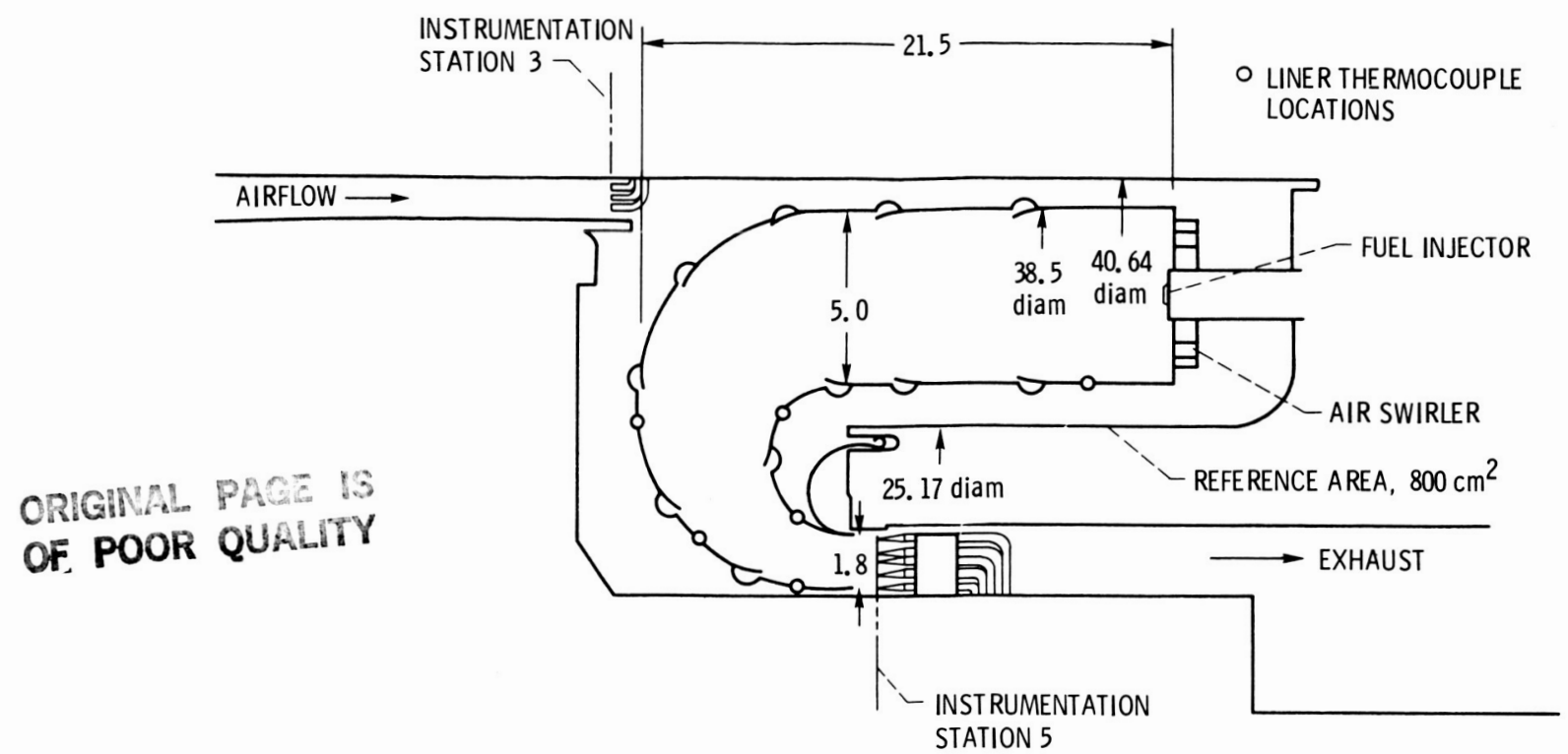

(a)

COMBUSTOR CENTERLINE

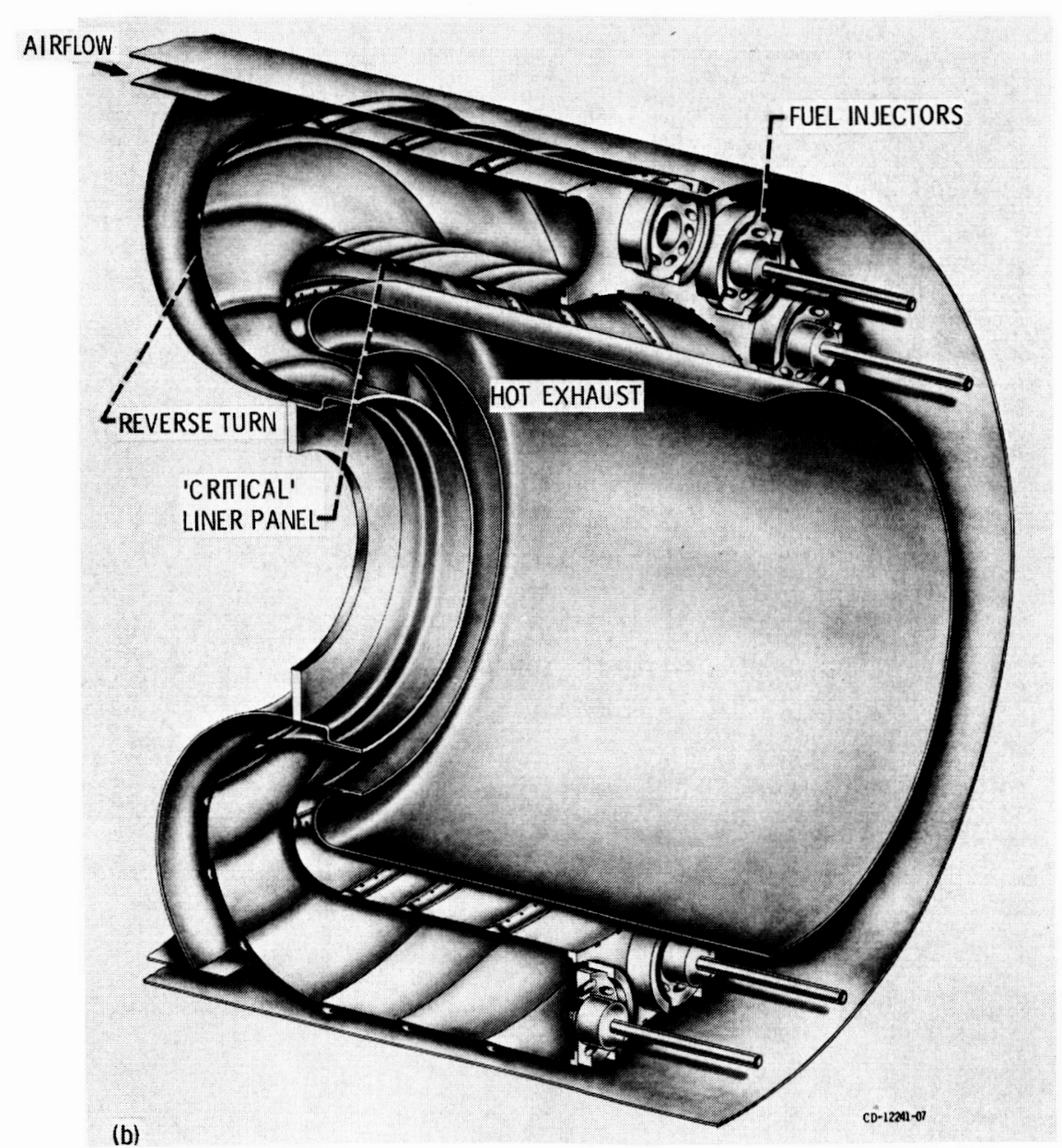

(a) Cross section.

(b) Isometric view.

FIGURE 2. - REVERSE-FLOW COMBUSTOR. (ALL DIMENSIONS ARE IN CENTIMETERS.) 


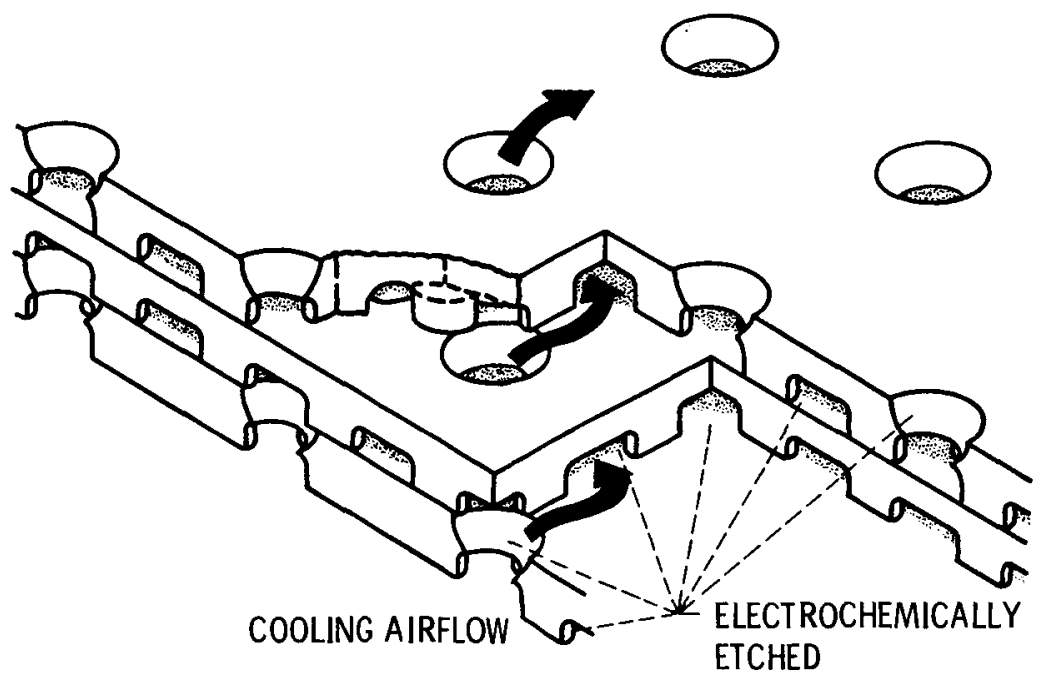

FIGURE 3. - SCHEMATIC OF LAMILLOY LINER COOLING CONFIGURATION.

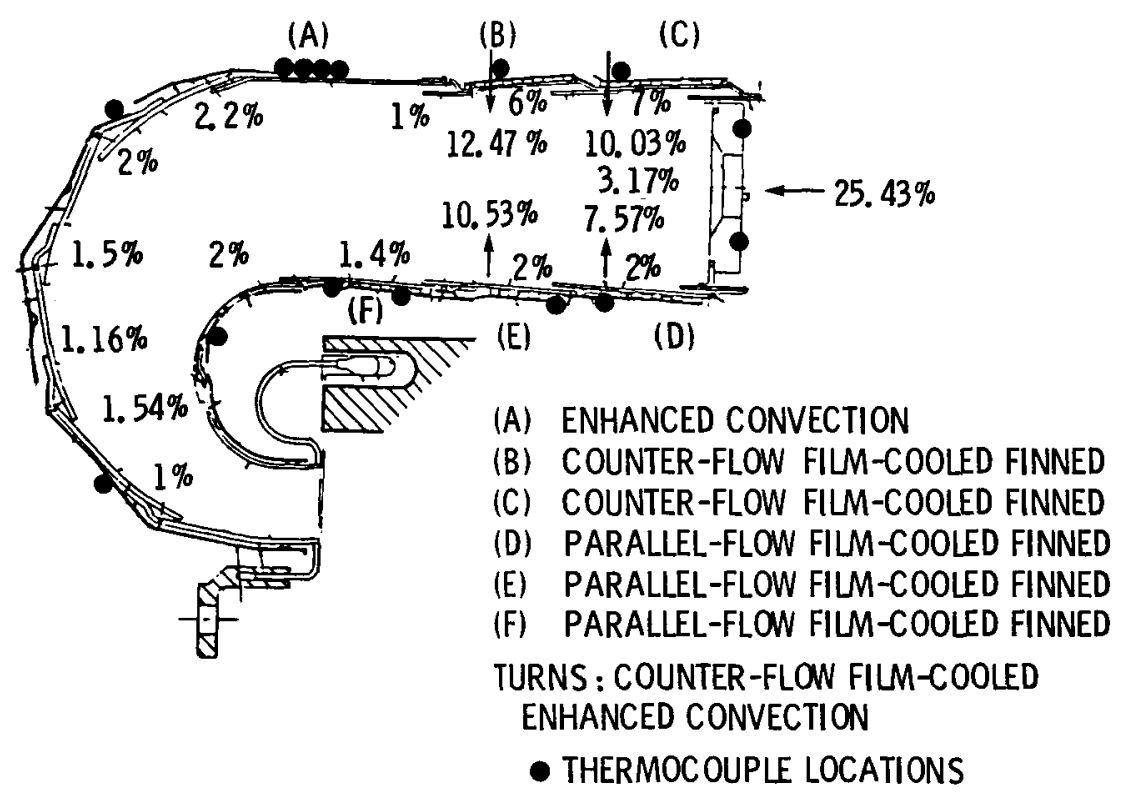

FIGURE 4. - CROSS-SECTIONAL VIEW OF COUNTER-FLOW FILM-COOLED REVERSE FLOW COMBUSTION LINER INCLUDING CALCULATED AIR-FLOW DISTRIBUTION. 


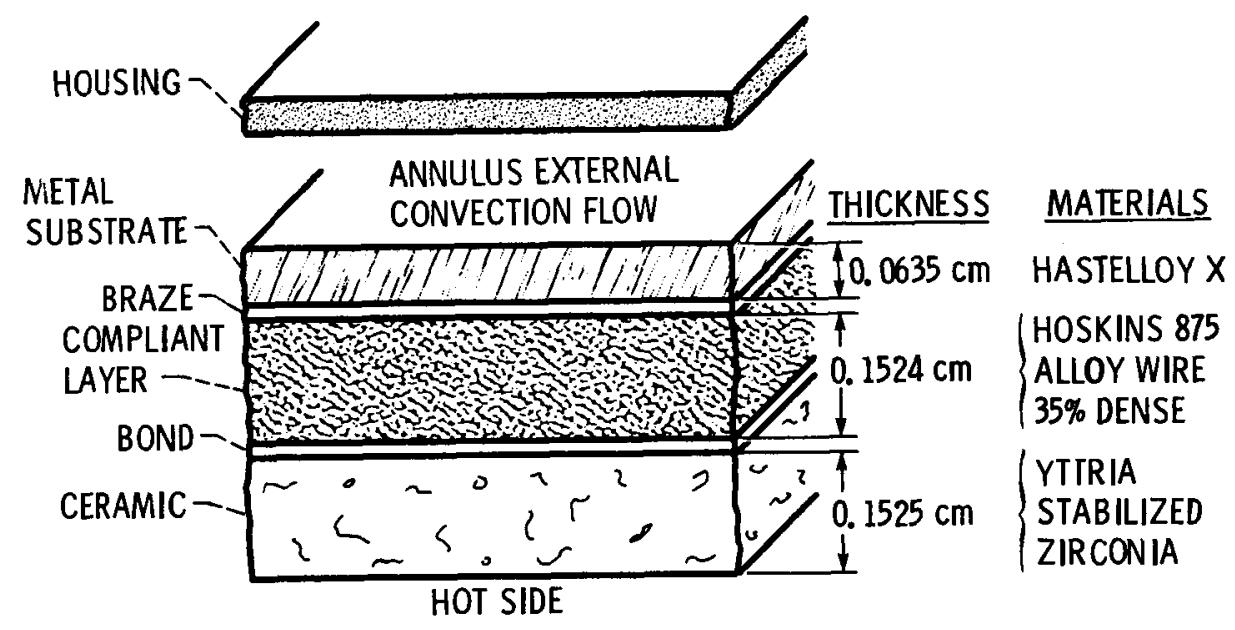

FIGURE 5. - CROSS SECTION OF THE COMPLIANT METAL/CERAMIC LINER CONCEPT. (NOT TO SCALE.) 


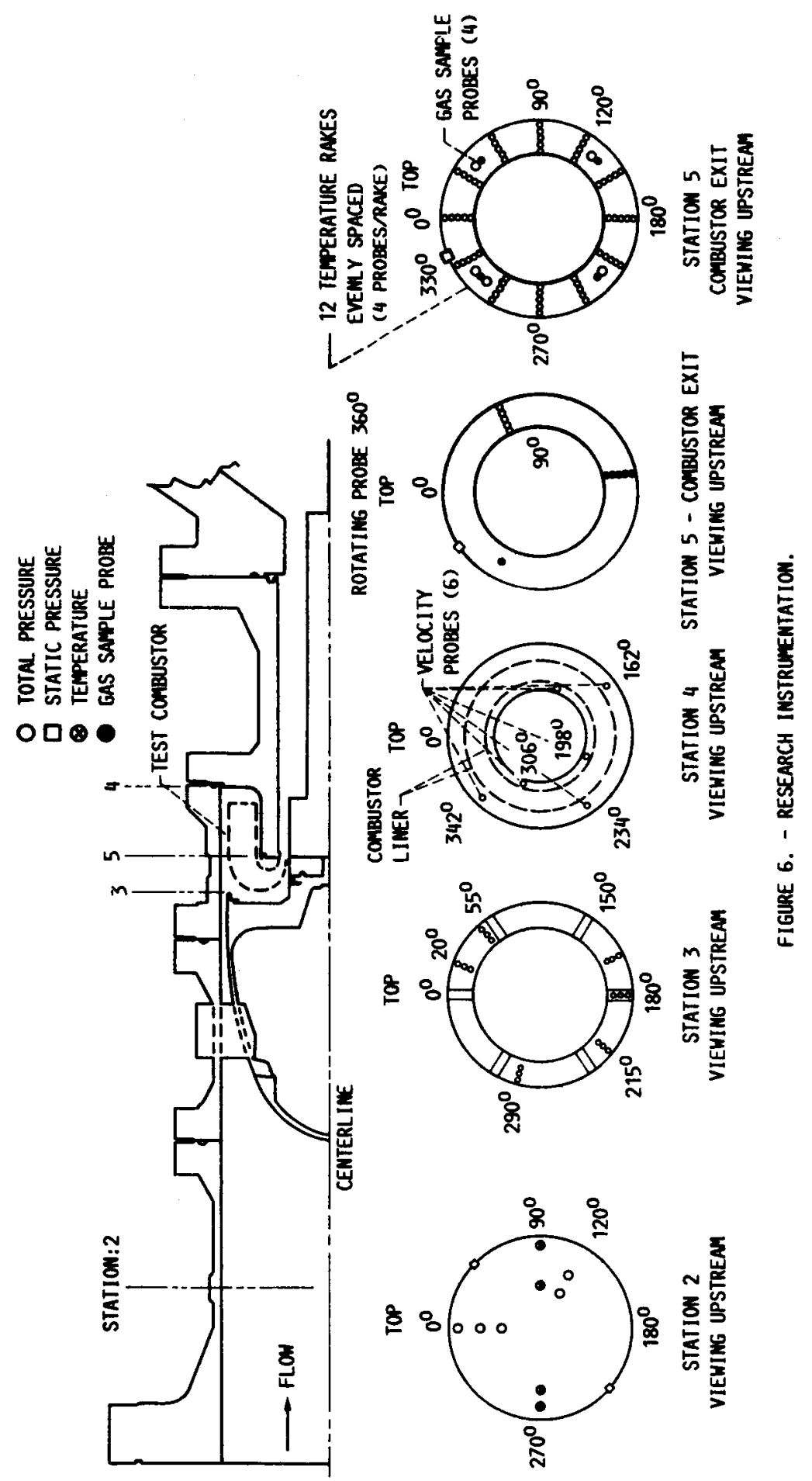




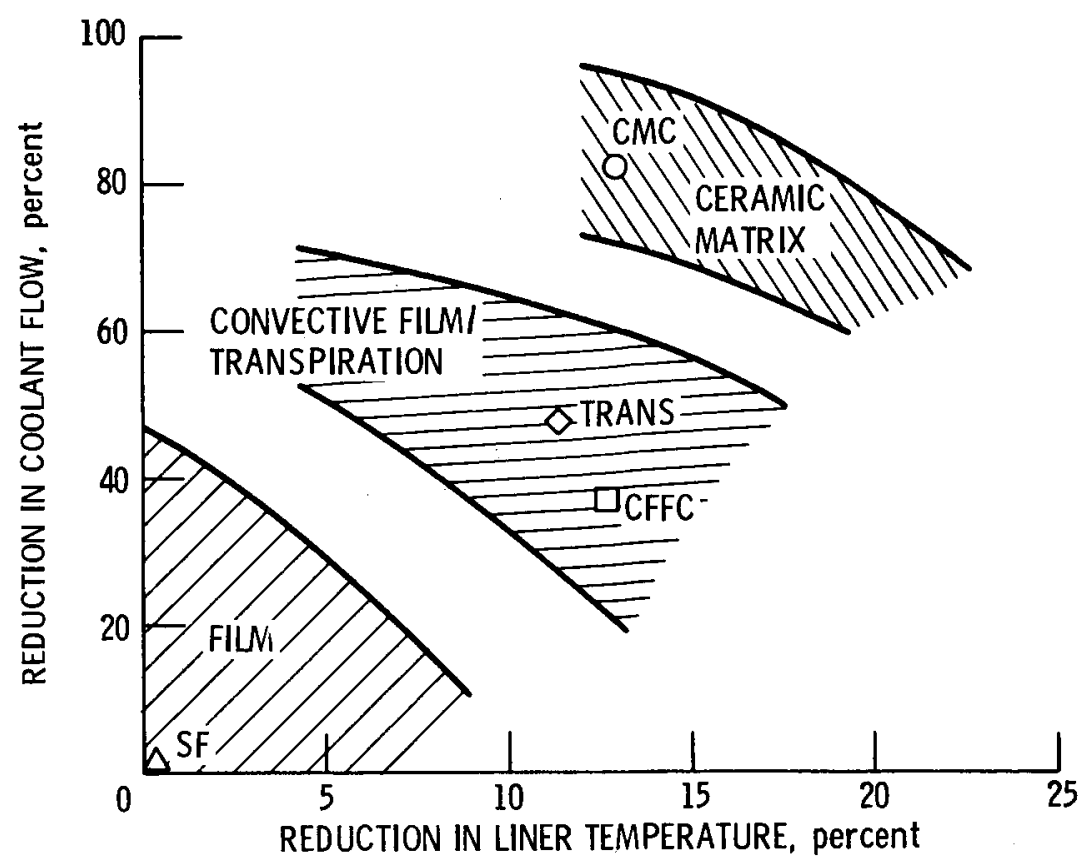

FIGURE 7. - COMPARISON OF COOLING EFFECTIVENESS FROM A COMPLIANT METAL/CERAMIC (CMC) LINER WITH A COUNTER-FLOW FILMCOOLED (CFFC) LINER, A LAMILLOY (TRANS) LINER, AND A SPLASH FILM (SF) LINER.

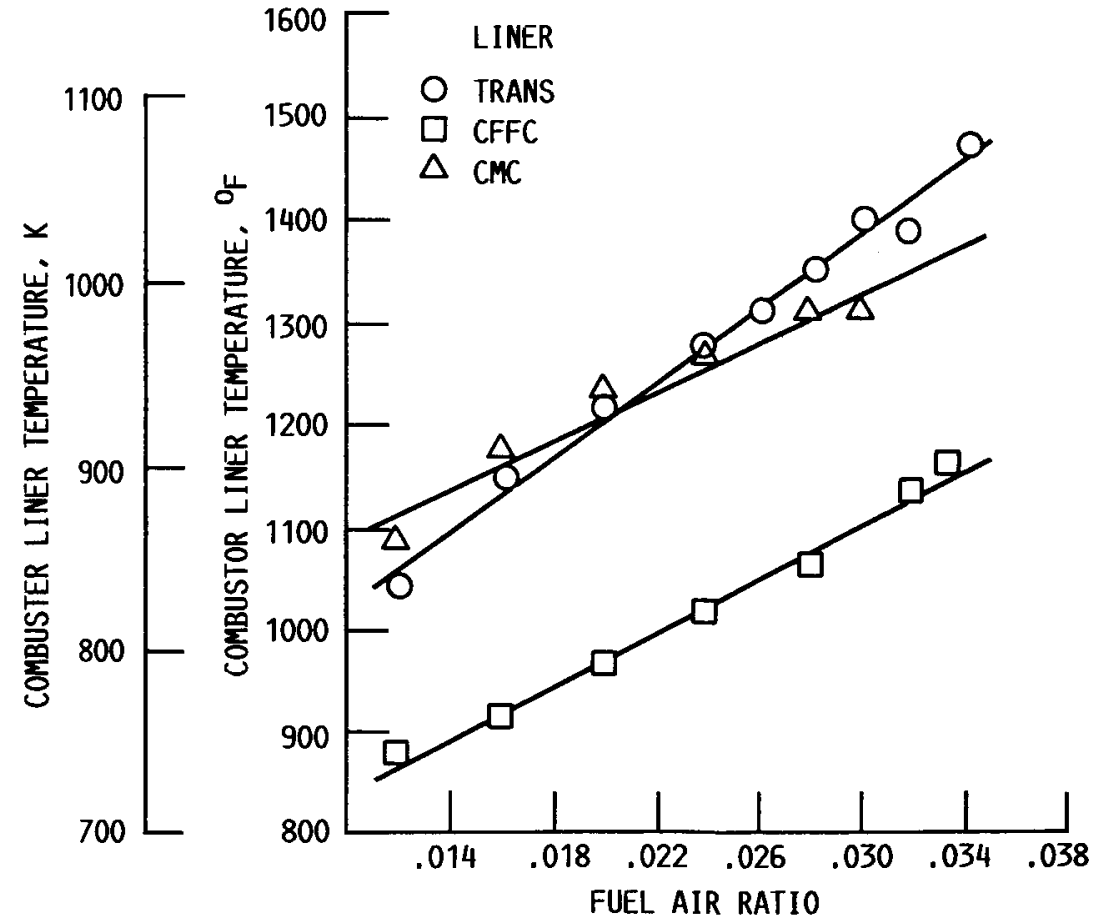

FIGURE 8. - LINER TEMPERATURE COMPARISON FOR THE INNER LINER PRIOR TO THE TURN. INLET PRESSURE, 1620 KPA (235 PSIA): INLET TEMPERATURE, $717 \mathrm{~K}\left(830^{\circ} \mathrm{F}\right)$; TOTAL AIRFLOW, 3.63 $\mathrm{KG} / \mathrm{SEC}(8 \mathrm{LB} / \mathrm{SEC})$. 


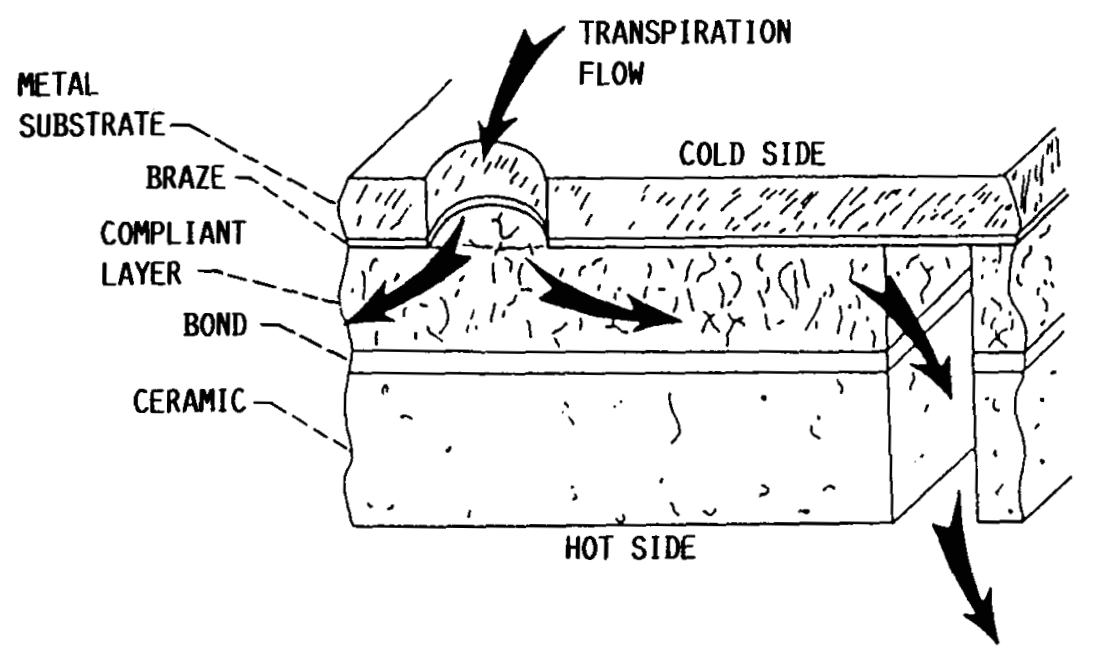

FIGURE 9. - COMPLIANT METAL/CERAMIC LINER CONCEPT FOR A $3000^{\circ} \mathrm{F}$ COMBUSTOR EXIT TEMPERATURE. 


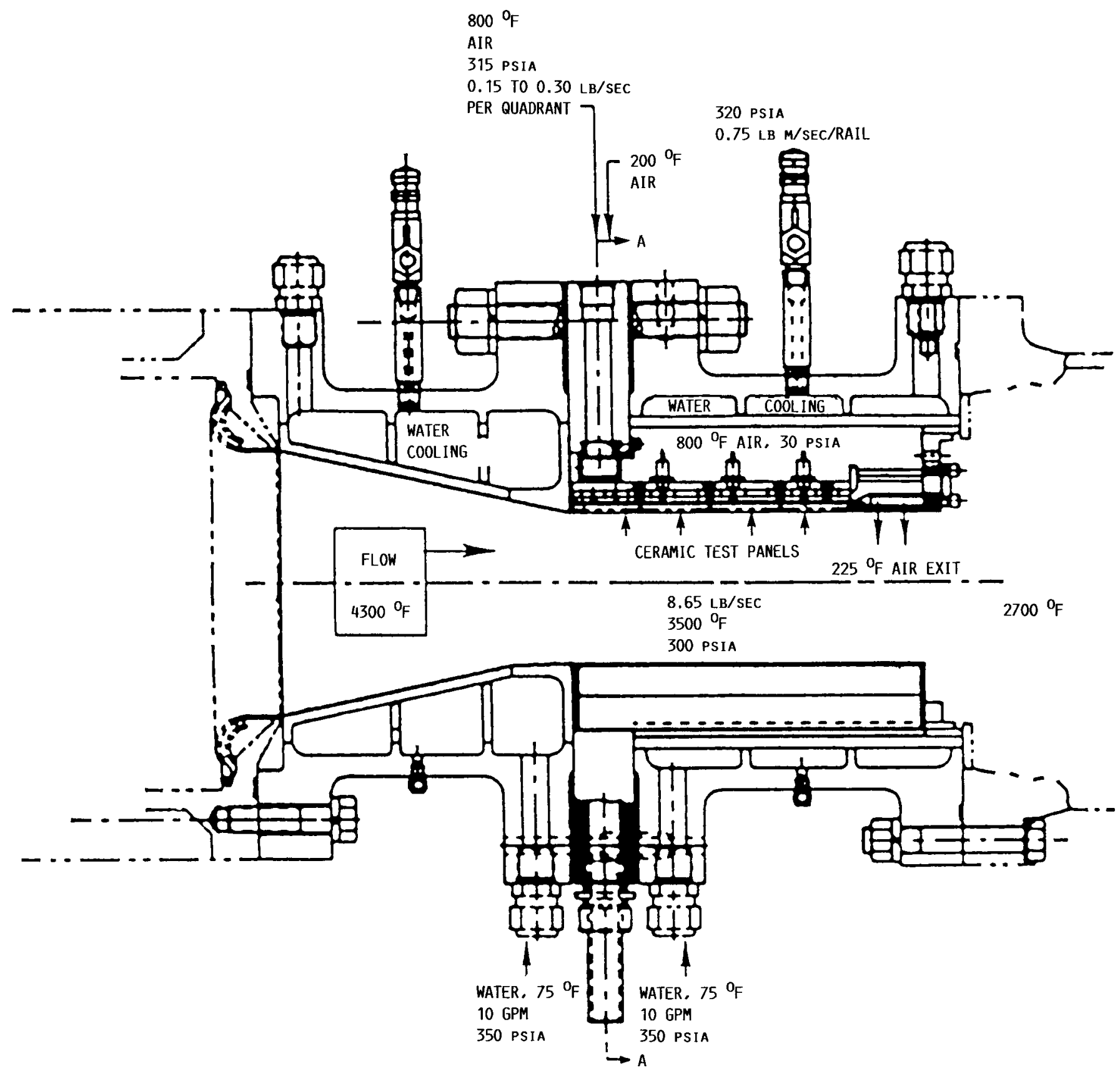

FIGURE 10. - CERAMIC MATRIX LINER TEST RIG LAYOUT, KEY TEMPERATURE, FLOW. AND PRESSURE CONDITIONS, UNDER DESIGN CONDITIONS, ARE INDICATED. 


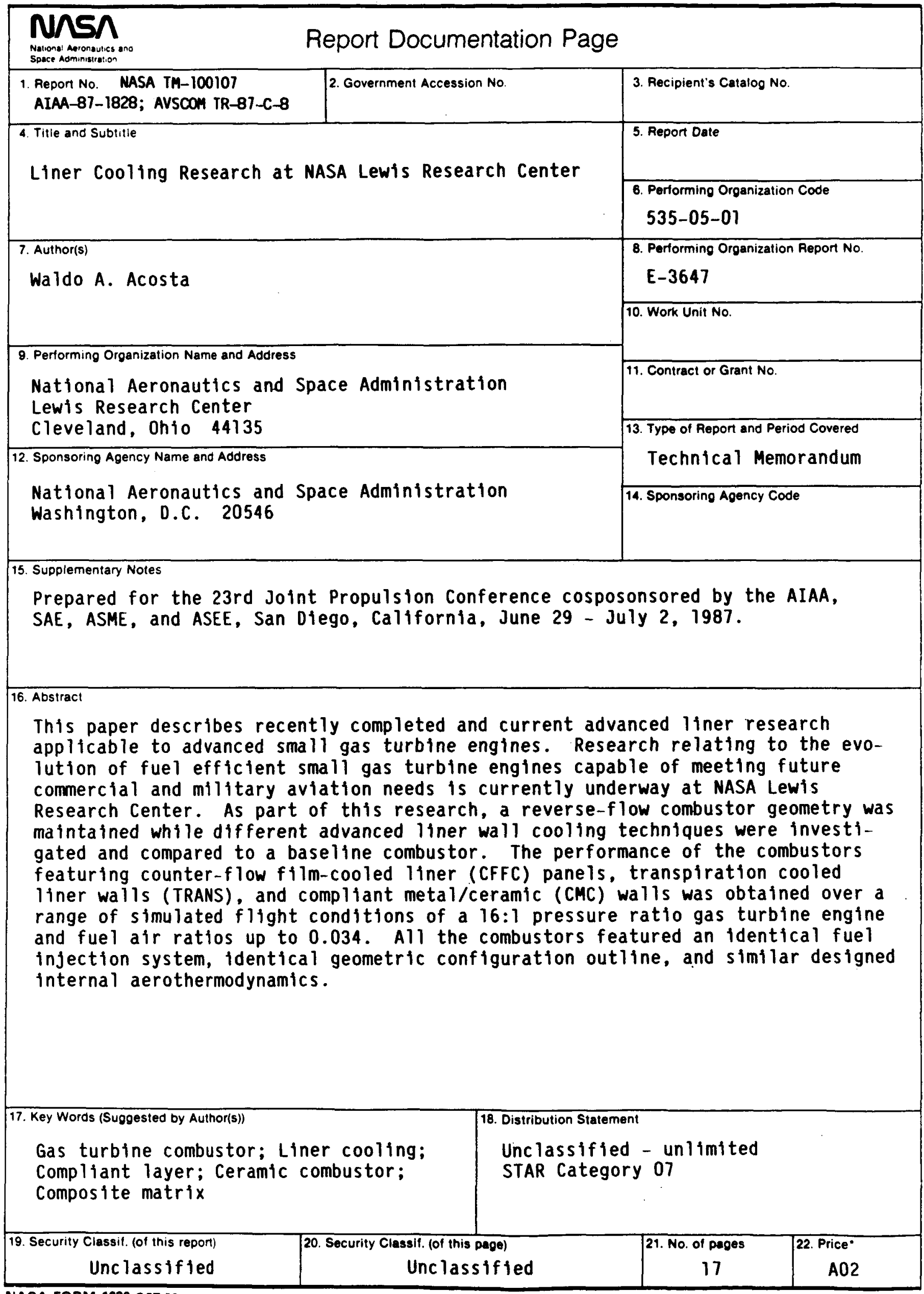

NASA FORM 1626 OCT 86 "For sale by the National Technical Information Service, Springfield, Virginia 22161 